\title{
Wpływ diety niskowęglowodanowej na stan zdrowia człowieka
}

\section{The impact of a low-carbohydrate diet on human health}

\author{
Martyna Zielińska ${ }^{1 凶}$, Jadwiga Buczkowska-Radlińska² \\ 1 Pomorski Uniwersytet Medyczny w Szczecinie, Studium Doktoranckie Katedry i Zakładu Stomatologii Zachowawczej i Endodoncji, \\ al. Powstańców Wlkp. 72, 70-111 Szczecin \\ ${ }_{2}^{2}$ Pomorski Uniwersytet Medyczny w Szczecinie, Katedra i Zakład Stomatologii Zachowawczej i Endodoncji, al. Powstańców Wlkp. 72, 70-111 Szczecin \\ $\triangle$ martyna.zielinska.88@gmail.com
}

\begin{abstract}
The low carbohydrate diet is the most controversial eating model of the last few years. It reverses the well known food pyramid based on carbohydrates. Instead, it recommends eating a lot of fats, including from animal sources. Recommended by many dieticians and doctors, but denied and underestimated by others, it has became quite a mystery. This way of eating has accompanied human kind from its beginnings. Unfortunately, along with the development of civilization and the introduction of
\end{abstract}

\section{ABSTRAKT}

Dieta niskowęglowodanowa budzi najwięcej kontrowersji spośród wszystkich modeli żywienia ostatnich lat. Odwraca znaną wszystkim piramidę żywienia, demonizuje stanowiące jej podstawę węglowodany oraz zaleca spożywanie dużych ilości tłuszczów, także tych zwierzęcych. Polecana przez wielu dietetyków i lekarzy, negowana i niedoceniana przez innych, wciąż stanowi wielką zagadkę. Taki sposób żywienia towarzyszył ludzkości od początków istnienia, jednak wraz z rozwojem processed, tasty, carbohydrate-stuffed foods, it lost its popularity. There are many reports that prove the positive effects of a low-carbohydrate diet on human health.

The goal of this paper was to gather all available data known about the impact of a low-carbohydrate diet on human general and oral health and the condition of the teeth.

Keywords: ketogenic diet; carbohydrate-restricted diet; paleolithic diet. cywilizacji, po wprowadzeniu przetworzonych produktów bogatych w węglowodany, stracił na popularności. Istnieje wiele doniesień na temat pozytywnego wpływu diety ograniczającej podaż węglowodanów na stan zdrowia człowieka.

Celem pracy było zebranie dostępnych informacji na temat oddziaływania diety niskowęglowodanowej na zdrowie ogólne człowieka oraz uzębienie i stan jamy ustnej.

Słowa kluczowe: dieta ketogeniczna; dieta ograniczająca węglowodany; paleo.

\section{WSTĘP}

Od lat trwa spór o przyczynę powstawania schorzeń ogólnoustrojowych. Wciąż panujący pogląd, zgodnie z którym tłuszcze w diecie odpowiedzialne są m.in. za choroby krążenia, metaboliczne, otyłość i nowotwory, zaczyna powoli odchodzić do przeszłości.

W ciągu ostatnich kilku dziesięcioleci znacząco wzrosła zachorowalność na choroby cywilizacyjne takie jak próchnica zębów, cukrzyca, choroby układu sercowo-naczyniowego i nowotwory. Za sprawą Ancela Keysa spożywaniu tłuszczów zaczęto przypisywać powodowanie wszelkich patologii. Jednak od czasu wprowadzenia jego teorii znacząco spadła konsumpcja tłuszczy, zwłaszcza tych zwierzęcych, natomiast zapadalność na wymienione schorzenia wciąż wzrasta. Jednocześnie nastąpił wzrost spożycia cukrów - od początku XX w. roczne spożycie cukru na osobę wzrosło z 5 do $100 \mathrm{~kg}$. Dane te sugerują konieczność odrzucenia poglądu o szkodliwości tłuszczu i zmianę zaleceń dietetycznych dla ogółu populacji [1].

\section{DIETA NISKOWĘGLOWODANOWA}

Dieta niskowęglowodanowa charakteryzuje się niską podażą węglowodanów, wynoszącą maksymalnie do $25 \%$ dziennego zapotrzebowania kalorycznego. Jest to wartość uważana za minimalną, konieczną do prawidłowego funkcjonowania tkanek i narządów zależnych od glukozy. Wyróżnić można również skrajnie niskowęglowodanową dietę ketogeniczną, w której podaż węglowodanów wynosi poniżej 10\% dziennego zapotrzebowania kalorycznego lub poniżej $50 \mathrm{~g}$ na dobę. Przy takim poziomie dochodzi w organizmie do zmian metabolicznych podobnych do obserwowanych w stanie głodzenia ketozy. W warunkach niedoboru glukozy organizm przechodzi w stan oszczędzania jej dla procesów od niej zależnych. Zmienia się preferencja utleniania dostępnych substratów energetycznych, w pierwszej kolejności utlenieniu podlegają ciała ketonowe, np. octan i inne krótkołańcuchowe kwasy tłuszczowe, następnie wolne kwasy tłuszczowe, a na końcu glukoza (tab. 1). Spadek wydzielania insuliny powoduje zahamowanie procesu lipogenezy oraz wiąże się ze zwiększonym 
TABELA 1. Źródła energii w diecie ketogenicznej [2]

\begin{tabular}{l}
\hline Kwasy tłuszczowe ( $70 \%$ zapotrzebowania kalorycznego) \\
Tłuszcze z diety \\
Lipoliza \\
Zasoby z tkanki tłuszczowej \\
Ciała ketonowe ( $20 \%$ zapotrzebowania kalorycznego) \\
Tłuszcze i białko z diety \\
Lipoliza i ketogeneza \\
Zasoby z tkanki tłuszczowej \\
Glukoza ( $10 \%$ zapotrzebowania kalorycznego) \\
Glukoneogeneza \\
Tłuszcze i białko z diety (glicerol) \\
Glikogenoliza
\end{tabular}

wydzielaniem glukagonu. Dochodzi do zwiększenia lipolizy i powstawania ciał ketonowych będących alternatywnym paliwem dla mitochondriów. Ciała ketonowe wchodzące w cykl Krebsa są wydajnym źródłem energii dla komórek organizmu. Poziom ciał ketonowych można bez trudu zbadać w moczu [3].

Za niski uznaje się najniższy poziom spożycia węglowodanów, przy którym jeszcze nie obserwuje się objawów ketozy, czyli nie stwierdza się ciał ketonowych we krwi oraz w moczu. Mieści się on w zakresie 50-130 g węglowodanów na dobę lub 10-25\% dziennych kalorii pochodzących z węglowodanów. Bardzo niski poziom węglowodanów w diecie, przy którym pojawiają się ciała ketonowe we krwi, to poniżej 50 g węglowodanów na dobę lub poniżej $10 \%$ dziennych kalorii. W diecie o średnim poziomie węglowodanów ich podaż wynosi $26-45 \%$, a w wysokowęglowodanowej powyżej 45\% (tab. 2) [2, 4, 5, 6].

Według zaleceń Światowej Organizacji Zdrowia dieta powinna składać się w 45-65\% z węglowodanów, w ok. 25-35\% z tłuszczów oraz w 10-15\% z białka [7]. Taki skład opiera się na powszechnie znanym stwierdzeniu, że ludzki organizm potrzebuje glukozy jako głównego źródła energii. Jednak bezpośrednio zależne od dowozu glukozy są jedynie tkanka mózgowa, białe i czerwone ciałka krwi oraz kora nerki. Całkowite minimalne zapotrzebowanie organizmu na węglowodany mieści się w granicach 110-140 g/dobę. Wyniki badań wskazują jednak, że nawet tkanki zależne od glukozy w warunkach głodzenia, czyli niewystarczającej dla organizmu podaży glukozy, potrafią przynajmniej częściowo się przystosować do metabolizmu tłuszczów. Ludzki mózg zaadaptowany do niskiego poziomu węglowodanów potrafi czerpać nawet 50\% energii z ciał ketonowych. Ponadto w wątrobie oraz nerkach na drodze glukoneogenezy produkowana jest glukoza z tzw. aminokwasów glukogennych, mleczanu oraz glicerolu, dzięki czemu przy normalnej podaży węglowodanów powstaje na dobę ok. $30 \mathrm{~g}$ glukozy. Podczas głodzenia nawet do 200 g glukozy dziennie może być stworzonych na tym szlaku. Taka ilość wystarczająco zaspokaja zapotrzebowanie tkanek zależnych od glukozy $[2,3]$.

Diety ograniczające podaż węglowodanów cieszą się w ostatnich latach coraz większym zainteresowaniem. Jako pierwszy taki sposób odżywiania opisał William Banting w 1863 r. w broszurze „Listy o otyłości”. Jego dieta, określana jako odchudzająca, zakładała rezygnację ze spożywania pieczywa, masła, mleka, cukru, piwa oraz ziemniaków. Pomimo ogromnego zainteresowania oraz sukcesu diety obecnie nikt nie kojarzy Bantinga jako twórcy diety niskowęglowodanowej [8].

Podobne założenia wprowadził nieco później znacznie bardziej znany Robert Atkins, który w latach 1972-2003 wydał 17 książek na temat niskowęglowodanowego odżywiania. Dieta Atkinsa skrajnie ogranicza podaż węglowodanów do nawet $30 \mathrm{~g} /$ dobę, zwiększając ilość białka oraz tłuszczów, pozwalając przy tym na ich nieograniczone spożycie. Dieta Atkinsa składa się z kilku etapów. W pierwszym wstępnym okresie, trwającym 2 tyg., spożycie węglowodanów ograniczone jest do $30 \mathrm{~g} /$ dobę i jedynym ich źródłem są warzywa nieskrobiowe. Jest to kluczowy okres przejścia w stan ketozy. Po adaptacji do zmniejszonej podaży glukozy oraz po uzyskaniu pewnej redukcji masy ciała stopniowo zwiększane jest spożycie węglowodanów, których wprowadza się o $10 \mathrm{~g}$ więcej na tydzień. Po uzyskaniu satysfakcjonującej masy ciała spożycie węglowodanów ustala się na takim poziomie, aby waga ciała nie ulegała zmianie. Następuje okres podtrzymujący, który jest stały. Atkins pozwala wprowadzać do diety wysokotłuszczowe produkty nabiałowe, jaja, mięsa, ryby, warzywa oraz owoce i orzechy w późniejszych okresach [9].

Pisząc o dietach niskowęglowodanowych, nie można zapomnieć o modnej w ostatnich latach diecie paleo. Jest to model żywienia oparty na przykładowym jadłospisie naszych przodków z czasów paleolitu, którzy jedli wyłącznie to, co udało im się upolować lub zebrać (hunter-gatherer). Jest to dieta, w której dominują białka i tłuszcze, gdyż posiłki składają się głównie z różnego rodzaju mięs, ryb, jaj, warzyw i orzechów, natomiast podaż węglowodanów można dowolnie modyfikować, ponieważ dozwolone jest spożywanie owoców oraz niektórych warzyw skrobiowych. W niektórych modyfikacjach diety paleo dozwolone jest również spożywanie kasz oraz ryżu - jest to tzw. dieta samuraja, zalecana osobom intensywnie uprawiającym sporty [10].

TABELA 2. Definicje diet niskowęglowodanowych oraz zawartość węglowodanów w diecie

\begin{tabular}{llll}
\multicolumn{3}{c}{ Definicje diet z ograniczoną zawartością węglowodanów } \\
\hline & $\begin{array}{l}\text { dieta o bardzo niskiej zawartości } \\
\text { węglowodanów }\end{array}$ & $\begin{array}{l}\text { dieta o niskiej zawartości } \\
\text { węglowodanów }\end{array}$ & $\begin{array}{l}\text { dieta o umiarkowanej zawartości } \\
\text { węglowodanów }\end{array}$ \\
\hline Podaż węglowodanówów & $\begin{array}{l}20-50 \text { g/dobę i/lub <10\% całkowitej } \\
\text { podaży energetycznej przy } \\
\text { kaloryczności } 2000 \text { kcal/dobę }\end{array}$ & $\begin{array}{l}<0 \text { g/dobę i/lub <26\% całkowitej } \\
\text { podaży energetycznej }\end{array}$ & $\begin{array}{l}26-45 \% \text { całkowitej podaży } \\
\text { energetycznej }\end{array}$ \\
\hline Rekomendacja & $\begin{array}{ll}\text { zalecana jako wczesna faza w diecie } \\
\text { Atkinsa oraz w diecie Power Protein }\end{array}$ & $\begin{array}{l}\text { Amerykańskie Stowarzyszenie } \\
\text { Dietetyczne rekomenduje 130 g } \\
\text { węglowodanów na dobę jako } \\
\text { wartość minimalną }\end{array}$ \\
\hline
\end{tabular}


Innym modelem żywienia niskowęglowodanowego jest dieta Power Protein stworzona przez lekarzy Michaela i Mary Dan Eades. W założeniach najbardziej przypomina dietę paleo, jest jednak bardziej restrykcyjna w podaży węglowodanów. Niedozwolone jest spożywanie zbóż, produktów przetworzonych, cukru oraz w pewnych przypadkach nabiału. Jest to dieta wysokobiałkowa i wysokotłuszczowa [11].

Wiele badań wskazuje na prozdrowotny charakter diety paleo, gdyż człowiek jest genetycznie przystosowany do takiego modelu żywienia. Genom człowieka nie uległ zmianom od czasów paleolitu, jego dieta natomiast znacząco się zmieniła. Dieta paleo nie jest uboga w makroskładniki i mikroelementy, co jest często mylnie stawianym zarzutem wobec diet niskowęglowodanowych. 0 wyższości paleo nad dietą Atkinsa decyduje fakt, że eliminuje ona coraz częściej występujące w diecie alergeny - gluten i produkty nabiałowe $[10,12]$.

Dieta niskowęglowodanowa stała się przedmiotem wielu badań w ostatnich latach. Wciąż oceniany jest jej wpływ na zdrowie ogólne, udział w leczeniu chorób metabolicznych, otyłości, padaczki, chorób układu krążenia, a nawet nowotworów. Brakuje ocen długoterminowego działania tego typu diety, gdyż większość badań klinicznych zamykana jest po roku trwania, ale mimo wszystko wyniki są obiecujące.

Przez wiele lat ten model odżywiania spotykał się z krytyką ze strony kręgów medycznych jako przeciwstawiający się powszechnie panującemu poglądowi, iż tłuszcze odpowiedzialne są za otyłość i choroby układu krążenia. Liczne wyniki badań dotyczące diet wysokotłuszczowych pokazały jednak, że ograniczając spożycie węglowodanów, uzyskuje się bardzo wiele pozytywnych, prozdrowotnych efektów, m.in. spadek masy ciała, zmniejszenie stężenia triglicerydów we krwi, ograniczenie uczucia głodu oraz poprawę wrażliwości tkanek na insulinę $[13,14,15]$.

\section{DIETA NISKOWĘGLOWODANOWA W LECZENIU CHORÓB CYWILIZACYJNYCH}

Zmiany dietetyczne najczęściej kojarzone są z walką z otyłością. Wiele badań klinicznych przeprowadzono po to, aby uzyskać informacje na temat przydatności zmian modelu żywienia w walce z nadwagą. Większość badaczy jest zgodna, iż dieta ograniczająca węglowodany w porównaniu z dietą niskotłuszczową prowadzi do większego ubytku masy ciała. Niektórzy badacze podchodzą jednak sceptycznie do diety niskowęglowodanowej jako odchudzającej, wskazując, że ubytek masy ciała jest skutkiem wypłukiwania glikogenu mięśniowego i spadku retencji wody $[16,17]$. Dane potwierdzają jednak długoterminowość spadku masy ciała u osób ograniczających podaż węglowodanów w porównaniu z osobami na diecie niskotłuszczowej $[18,19,20,21,22]$. Największe różnice w utracie masy ciała widoczne są w trakcie pierwszych 6 miesięcy stosowania diety, podczas gdy po blisko roku różnice nie są już statystycznie istotne. Istotnym czynnikiem przemawiającym na korzyść diety niskowęglowodanowej jest niski odsetek osób odstępujących od badań, co wskazuje na lepszą tolerancję takiego modelu żywienia. Jednocześnie ten sposób odżywiania zapewnia uczucie sytości, dzięki czemu łatwiej uzyskać i utrzymać satysfakcjonujący deficyt kaloryczny. Jest to warunkowane dość dużym poziomem białka w diecie, którego trawienie trwa długo i zapewnia uczucie sytości $[2,18,19,20,21,22]$.

Powszechnie panuje pogląd, iż wysoki poziom tłuszczów w diecie wiąże się ze zwiększoną zapadalnością na choroby układu krążenia. Tłuszcze uznawane są za czynnik negatywnie wpływający na zdrowie ogólne, poziom lipoproteiny o niskiej gęstości (LDL) i lipoproteiny o wysokiej gęstości (HDL) oraz rozwój arteriosklerozy. Wyniki badań na zdrowych ochotnikach wskazują jednak, że diety niskowęglowodanowe zmniejszają ryzyko chorób serca, zwiększając poziom HDL, zmniejszając poziom triglicerydów oraz ciśnienie krwi, jednocześnie nieznacznie zwiększając poziom LDL oraz cholesterolu całkowitego [21, 22, 23, 24].

Restrykcje węglowodanów wpływają korzystnie na dyslipidemię poprzez zmniejszenie wydzielania przez wątrobę VLDL, czego rezultatem jest spadek triglicerydów we krwi, a także zmniejszając hydrolizę HDL, co skutkuje wzrostem stężenia HDL [21, 25, 26].

W badaniu Ruth i wsp. przeprowadzonym na 55 osobach zaobserwowano spadek masy ciała o ponad 5\% u 78\% osób z grupy będącej na diecie niskowęglowodanowej w porównaniu z 53\% w grupie będącej na diecie niskotłuszczowej. Stwierdzono także spadek wartości ciśnienia skurczowego oraz rozkurczowego w grupie niskowęglowodanowej, czego nie zaobserwowano w grupie niskotłuszczowej. W obu grupach zaobserwowano podobny spadek w tkance mięśniowej i tłuszczowej. Badanie nie wykazało również zmian w poziomie insuliny oraz glukozy na czczo w obu grupach. Pomimo podobnych założeń kalorycznych w grupie na diecie niskowęglowodanowej po 12 tyg. zauważono spadek poziomu triglicerydów o 23\% oraz wzrost poziomu HDL o 11\% w porównaniu z grupą na diecie niskotłuszczowej, w której nie dostrzeżono żadnych zmian badanych markerów [26].

Ponadto wyniki badań wskazują na pozytywny wpływ diety niskowęglowodanowej na markery zapalne we krwi związane z ryzykiem chorób układu krążenia. Zaobserwowano spadek stężenia w surowicy hs-CRP (białka powiązanego ze zwiększonym ryzykiem chorób układu krążenia) u osób ograniczających spożycie węglowodanów w porównaniu z osobami na diecie niskotłuszczowej. Innym czynnikiem działającym na korzyść układu sercowo-naczyniowego jest adiponektyna, której zwiększające wrażliwość insulinową oraz przeciwzapalne działanie pozytywnie koreluje z ryzykiem chorób serca. Zaobserwowano zwiększone całkowite stężenie adiponektyny u osób na diecie niskowęglowodanowej. Niektórzy autorzy sugerują także pozytywny wpływ diet niskowęglowodanowych na funkcję śródbłonka naczyń, cytokiny prozapalne oraz stężenie homocysteiny, jednak wymaga to szerszych badań klinicznych ze względu na małą liczebność prób [25, 26].

Kolejnym parametrem, na który korzystnie wpływa restrykcja węglowodanów w diecie, jest ciśnienie krwi, zarówno skurczowe, jak i rozkurczowe. Wyniki badań wskazują na spadek 
skurczowego i rozkurczowego ciśnienia krwi u osób stosujących dietę niskowęglowodanową [13, 14, 15, 19].

Większość opisanych parametrów porównywana była między grupami spożywającymi dietę niskowęglowodanową, niskotłuszczową lub zbilansowaną i wskazywała na bardziej korzystne lub przynajmniej porównywalne efekty diety białkowo-tłuszczowej w porównaniu z pozostałymi.

Mianem zespołu metabolicznego określa się zbiór współwystępujących czynników zwiększających ryzyko wystąpienia cukrzycy typu 2, rozwoju miażdżycy oraz ich powikłań naczyniowych. Do składowych zespołu metabolicznego zalicza się: otyłość brzuszną, nadciśnienie tętnicze, podwyższoną glikemię na czczo oraz dyslipidemię - niskie stężenie HDL, wysoki poziom triglicerydów, LDL oraz cholesterolu. Niektórzy badacze wskazują, że wspólną przyczyną powstawania wszystkich tych zaburzeń jest nadmierna konsumpcja węglowodanów, a w szczególności cukrów prostych. Diety niskowęglowodanowe, a zwłaszcza ketogeniczne, wpływają korzystnie na parametry zespołu metabolicznego. Przestawienie organizmu na metabolizm tłuszczów umożliwia spalanie tkanki tłuszczowej oraz redukcję wagi. Zmniejszenie poziomu glukozy we krwi skutkuje poprawą wrażliwości tkanek na insulinę, redukując insulinooporność i eliminując konieczność przyjmowania leków przeciwcukrzycowych [13, 14, 15, 19].

Już Hipokrates wprowadzał przedłużone posty jako terapię zapobiegającą napadom padaczkowym. W latach 20. XX w. dr R.M. Wilder jako metodę leczenia lekoopornej padaczki wprowadził dietę, w której znaczna ilość kalorii pochodziła z tłuszczów, co miało na celu wytworzenie biochemicznych zmian naśladujących głodówkę. Zmiana metabolizmu na tłuszczowy oraz korzystanie tkanki mózgowej z ciał ketonowych jako źródła energii zamiast glukozy zmniejsza potencjał drgawkowy mózgu. Obecnie, ze względu na dostępność farmakoterapii, leczenie za pomocą diety ograniczone jest do przypadków padaczki lekoopornej, jednak coraz więcej badaczy ze względu na skutki uboczne leków przeciwpadaczkowych powraca do leczenia epilepsji za pomocą diety. W badaniach potwierdza się skuteczność stosowania zmodyfikowanej diety Atkinsa, diety ketogenicznej oraz opartej na niskim indeksie glikemicznym. Badacze wskazują na zmniejszenie częstości napadów padaczkowych o ponad 50\% po 3 miesiącach stosowania diety. Amari i wsp. zauważyli korelację między preferencją produktów bogatych w tłuszcze a redukcją napadów padaczkowych u 30 pediatrycznych pacjentów z epilepsją. Stwierdzili 90-100\% redukcję napadów padaczkowych po roku stosowania zmodyfikowanej diety Atkinsa. Wśród wielu publikacji na temat wpływu diety ketogenicznej na redukcję napadów padaczkowych nie znaleziono badań negujących prawdziwość takiej korelacji $[27,28,29]$.

Diety ketogeniczne są przedmiotem wielu badań pod kątem ich przydatności w leczeniu chorób nowotworowych. Zauważono, że diety skrajnie niskowęglowodanowe wpływają na zmniejszenie guzów nowotworowych głowy i szyi. Otto Warburg spostrzegł wysoki poziom poboru glukozy przez guzy nowotworowe, na podstawie czego sformułował tezę, iż wzrost i metabolizm komórek nowotworowych uzależniony jest od glikolizy. Ograniczony dostęp do substratu uniemożliwia wzrost nowotworu, ale również poprawia stan ogólny pacjentów, zmniejszając kacheksję oraz poprawiając tolerancję chemio-i radioterapii. Ograniczając podaż węglowodanów, zmniejsza się tworzenie wolnych rodników tlenowych oraz stan zapalny tkanek, co dodatkowo chroni przed wzrostem nowotworu i działa protekcyjnie w stosunku do tkanek zdrowych. Dodatkowo, pomimo metabolicznej adaptacji organizmu imitującej stan głodzenia, możliwe jest spożywanie liczby kalorii adekwatnej do zapotrzebowania, co pozwala na prawidłowe funkcjonowanie oraz ochronę mięśni i tkanek przed katabolizmem. Badania kliniczne wśród osób terminalnie chorych na nowotwór wskazują na dobrą tolerancję diety ketogenicznej oraz jej korzystny wpływ na samopoczucie chorych przy braku skutków ubocznych [30, 31, 32, 33].

Podstawowa choroba jamy ustnej, choroba próchnicowa zębów, stała się w ciągu kilku ostatnich dziesięcioleci chorobą cywilizacyjną na skalę globalną. Obecnie znalezienie osoby, która nie cierpiałaby z powodu próchnicy, jest praktycznie niemożliwe. Jednak tysiące lat temu gatunek ludzki nie znał tej choroby [34]. Człowiek pierwotny w zależności od miejsca, w którym się urodził i żył, odżywiał się tym, co w danym miejscu był w stanie upolować lub zebrać. Jego dieta zatem obfitować mogła zarówno we wszelkiego rodzaju mięsa, jak i warzywa, owoce czy orzechy, w różnych proporcjach. Taka dieta zapewniała odpowiedni dowóz wszystkich makro- i mikroskładników koniecznych do prawidłowego funkcjonowania organizmu.

Badania kamienia nazębnego naszych przodków z okresu paleolitu, neolitu, średniowiecza oraz od okresu rewolucji przemysłowej do współczesności wskazują na to, że dieta stanowi jeden z najistotniejszych czynników wpływających na zmiany w ekosystemie jamy ustnej. Kamień nazębny stanowi zmineralizowaną płytkę nazębną, twardy złóg ściśle przylegający do tkanek zęba, niemożliwy do oczyszczenia poprzez zwykłe szczotkowanie zębów. Jest on idealnym źródłem wiedzy na temat składu bakteryjnego płytki nazębnej, gdyż bakterie w nim zamknięte nie ulegają degradacji wraz z upływem czasu. Umożliwia to uzyskanie informacji o zmianach mikrobiologicznych jamy ustnej zachodzących wraz z rozwojem cywilizacji. Badania szczątków ludzkich z okresu paleolitu (od ok. 2,5 mln do ok. 10 tys. lat p.n.e.) wskazują, że ówczesne sposoby odżywiania stanowiły dobrą profilaktykę przeciwko próchnicy oraz chorobom tkanek przyzębia. Przyczyniały się one do utrzymania mikrobiologicznej homeostazy jamy ustnej, dzięki czemu zapewniały dobry stan zdrowia. Próchnicę i zapalenie przyzębia stwierdzono jedynie w nielicznych przypadkach wśród szczątków z tego okresu. Dopiero wraz z rozwojem agrokultury w neolicie (10 000 lat p.n.e.) znacząco wzrosła liczba przypadków schorzeń jamy ustnej. Miało to związek ze wzrostem spożycia węglowodanów, co poprzez obniżenie pH w jamie ustnej wpłynęło na wzrost kolonii bakterii próchnicotwórczych z rodzaju Streptococcus oraz Lactobacillus. Wraz z rozwojem cywilizacji oraz wzrostem spożycia węglowodanów kolonie bakterii próchnicotwórczych zaczęły być coraz bardziej przeważającą grupą w ekosystemie jamy ustnej, natomiast najbardziej dominującymi stały się w okresie rewolucji przemysłowej 
(ok. 200 lat temu), kiedy to rozpoczęto tworzenie na szeroką skalę cukrów prostych oraz dwucukrów (sacharoza), a także przemysłowo przetworzonej mąki. Postęp cywilizacyjny wiąże się także z ogromnym spadkiem różnorodności mikroflory jamy ustnej, co skutkuje spadkiem odporności na niekorzystne zmiany w środowisku i wiąże się z występowaniem przewlekłych schorzeń organizmu [35, 36, 37, 38, 39].

W pierwszej połowie XX w. lekarz stomatolog Weston A. Price zaobserwował niezwykłe korelacje między sposobem odżywiania a stanem ogólnym i stanem jamy ustnej. Przemierzając rozmaite zakątki świata oraz poznając mieszkających i żyjących w różnych warunkach ludzi, zauważył, że społeczności odżywiające się żywnością naturalną wykazują odporność na choroby ogólne oraz stomatologiczne, a ich łuki zębowe są prawidłowo ukształtowane. Z kolei u społeczności, które przyjęły zachodni styl życia, bardzo szybko rozwijały się choroby ogólne oraz pojawiały się problemy z zębami i wady zgryzu o charakterze szkieletowym. Price za przyczynę tego stanu uważał przede wszystkim nadmierną konsumpcję przetworzonej żywności bogatej w cukry i idące w parze niedobory witaminowe. W szczególności zwrócił uwagę na niedobór witaminy D, która według niego miała działanie ochronne wobec zębów i kości. Obecnie funkcjonuje fundacja Westona A. Price’a zajmująca się edukacją w zakresie zdrowego żywienia [40].

Ancel Keys w latach 50. XX w. zaproponował teorię mówiącą, że tłuszcze w diecie odpowiedzialne są za rozwój przewlekłych chorób ogólnoustrojowych. Był on zwolennikiem diety niskotłuszczowej oraz wysokowęglowodanowej, uważając cukry za najważniejszy składnik żywienia, który zmniejsza ryzyko występowania chorób systemowych. Jednocześnie nie zaprzeczał, iż cukry są przyczyną powstawania próchnicy, jednak uważał to jedynie za miejscowy skutek uboczny zdrowej wg niego diety, niemający żadnego związku ze zdrowiem ogólnym człowieka. Jego teoria nie została potwierdzona podobnie jak nie uzyskano odpowiedzi na pytanie, dlaczego dieta zapobiegająca chorobom systemowym jednocześnie powoduje rozwój próchnicy i schorzenia przyzębia. Nigdy nie zostało potwierdzone, że dieta wysokowęglowodanowa jest środkiem na zdrowie i długowieczność [1].

Nieco później Thomas Cleave i John Yudkin, sprzeciwiając się teorii Keysa, postawili tezę, iż to nie tłuszcze stanowią problem żywieniowy, lecz spożywane w nadmiarze produkty bogate w cukry. Według ich teorii węglowodany są przyczyną tzw. przewlekłych niezakaźnych schorzeń stomatologicznych oraz ogólnoustrojowych. Ich hipoteza sugeruje, że próchnica zębów jest pierwszym objawem nieprawidłowego odżywiania. Problemy stomatologiczne pojawiają się jako pierwsze i stanowią swego rodzaju ostrzeżenie przed dalszym rozwojem chorób. Leczenie próchnicy bez zmian w odżywianiu i poprawy warunków mikrobiologicznych organizmu jest zatem tylko sposobem usunięcia objawów, bez ustalenia i eliminacji przyczyn. Teoria ta nadal jednak nie została potwierdzona żadnymi badaniami klinicznymi [1].

Dotychczas przeprowadzone badania na temat wpływu diety niskowęglowodanowej na choroby przyzębia sugerują jej działanie ochronne wobec dziąseł. We wszystkich badaniach

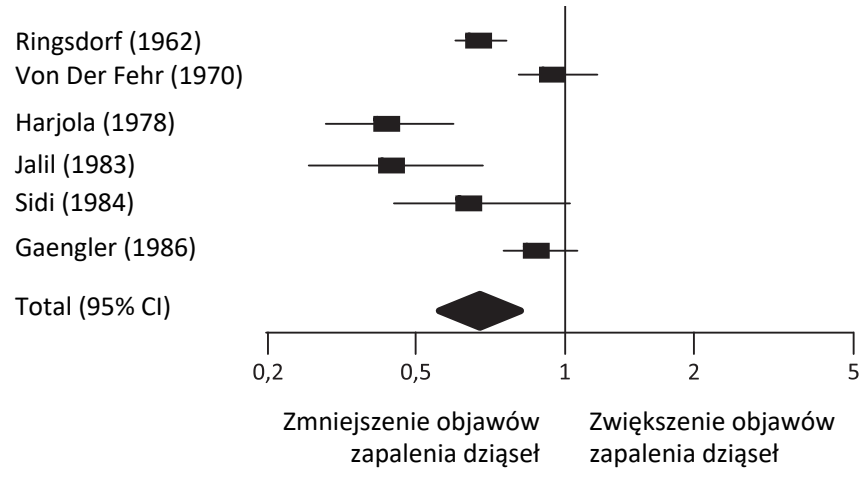

RYCINA 1. Wyniki badań klinicznych oceniających wpływ ograniczenia spożycia rafinowanych węglowodanów na zapalenie dziąseł

uzyskano zmniejszenie objawów zapalenia dziąseł pod wpływem ograniczenia spożywania cukrów (ryc. 1) [1].

W 2007 r. w Szwajcarii Baumgartner i wsp. [41] przeprowadzili doświadczenie z udziałem osób ze zdrowym przyzębiem w celu oceny wpływu diety z okresu kamienia łupanego na stan przyzębia przy braku higieny jamy ustnej. W eksperymencie wzięło udział 10 ochotników, którzy przez 4 tyg. mieli zamieszkać w warunkach, jakie panowały ok. 4000-3500 lat p.n.e., a także spożywać pożywienie z tamtej epoki. Dozwolone było spożywanie pełnych ziaren jęczmienia, pszenicy i orkiszu, mleka, miodu, soli, ziół, mięsa od zwierząt hodowlanych - kóz i kur, złowionych ryb, znalezionych borówek, jagód i warzyw. Uczestnicy nie mieli dostępu do cukrów rafinowanych, sprzętów kuchennych oraz środków higieny jamy ustnej. Po okresie 4 tyg. u badanych stwierdzono zwiększenie całkowitej masy płytki nazębnej bez skutków w obrębie tkanek przyzębia. Zarówno wskaźnik krwawienia dziąseł, jak i głębokość kieszonek przyzębnych uległy zmniejszeniu. Badania mikrobiologiczne pokazały wzrost ogólny kolonii bakteryjnych ze zwiększonym zróżnicowaniem bakteryjnym, natomiast liczebność bakterii odpowiedzialnych za choroby przyzębia i próchnicę spadła. Wyniki badań obalają teorię płytki niespecyficznej, potwierdzając, że to nie higiena jamy ustnej jest najistotniejszym orężem w walce z próchnicą i chorobami przyzębia. Brak higieny przy odpowiednim odżywianiu nie skutkuje rozwojem zapaleń przyzębia pomimo znacznego wzrostu całkowitej masy płytki nazębnej oraz liczebności i różnorodności bakterii.

Badania Al-Ahmada i wsp. [42] przyniosły zupełnie inny rezultat. W badaniach wzięło udział 7 ochotników, którzy przeszli na dietę opartą o pszenicę, warzywa, owoce, mięso i orzechy. Wynik eksperymentu był następujący: po okresie 8 tyg. stwierdzono wzrost liczebności bakterii, płytki nazębnej oraz wskaźnika krwawienia. U 4 dzieci stwierdzono progresję zmian próchnicowych zębów mlecznych.

Trudno wyciągnąć wnioski z wyników tylko tych dwóch badań. Oba eksperymenty wykonane były na grupach o małej liczebności, co mogło mieć wpływ na wyniki. Ponadto w badaniu Al-Ahmada i wsp. nie było możliwości kontroli tego, czy ochotnicy rzeczywiście utrzymywali standardy zalecanej diety oraz czy produkty zawarte w diecie 
były nieprzetworzone [42]. Wymagane są szersze badania na większej grupie osób, aby móc wyciągnąć właściwe wnioski na temat tego, czy dieta niskowęglowodanowa wpływa na profil mikrobiologiczny jednostki oraz w jaki sposób wpływa na stan jamy ustnej.

\section{PIŚMIENNICTWO}

1. Hujoel P. Dietary carbohydrates and dental-systemic diseases. J Dent Res 2009;88(6):490-502. doi: 10.1177/0022034509337700.

2. Westman CE, Feinman DR, Mavropoulos CJ. Low-carbohydrate nutrition and metabolism. Am J Clin Nutr 2007;86(2):276-84.

3. Murray RK, Granner KD, Rodwell WV. Biochemia Harpera. Warszawa: PZWL; 2015.

4. Last AR, Wilson SA. Low-carbohydrate diets. Am Fam Phys 2006;73(11):1943-8.

5. Crowe CT. Safety of low-carbohydrate diets. Obes Rev 2005;6(3):235-45. doi: 10.1111/j.1467-789X.2005.00196.x

6. Kargulewicz A. Dieta ketogeniczna - zastosowanie w praktyce klinicznej. Food Forum 2016;2(12):80-4.

7. Jarosz M, Bułhak-Jachymczyk B. Normy żywienia człowieka. Podstawy prewencji otyłości i chorób niezakaźnych. Warszawa: PZWL; 2008.

8. Banting W. Letter on corpulence. Addressed to the public. London; 1864.

9. Atkins RC. Atkins new diet revolution. New York: Avon Books; 2002.

10. Ople HL. Lifestyle and diet. Cardiovasc J Afr 2014;25(6):298-301. doi: 10.5830/CVJA-2014-063.

11. Eades MR, Eades MD. Protein power. New York: Bantam Books; 1996.

12. Frassetto LA, Schloetter M, Mietus-Synder M, Morris Jr RC, Sebastian A. Metabolic and physiologic improvements from consuming a paleolithic, hunter-gatherer type diet. Eur J Clin Nutr 2009;63(2):947-55. doi: 10.1038/ejcn.2009.4.

13. Spreadbury I. Comparison with ancestral diets suggests dense acellular carbohydrates promote an inflammatory microbiota, and may be the primary dietary cause of leptin resistance and obesity. Diabetes Metab Syndr Obes 2012;5:175-89. doi: 10.2147/DMSO.S33473.

14. Gadgil DM, Appel JL, Yeung E, Anderson CA, Sacks FM, Miller ER. The effects of carbohydrate, unsaturated fat, and protein intake on measures of insulin sensitivity. Diabetes Care 2013;36(5):1132-7. doi: 10.2337/dc12-0869.

15. Feinman DR, Pogozelski WK, Astrup A, Bernstein KR, Fine EJ, Westman CE, et al. Dietary carbohydrate restriction as the first approach in diabetes management: critical review and evidence base. Nutrition 2015;31(1):113. doi: 10.1016/j.nut.2014.06.011.

16. Denke AM. Metabolic effects of high-protein, low-carbohydrate diets. Am J Cardiol 2001;88(1):59-61.

17. Yang MU, Van Itallie TB. Composition of weight lost during short-term weight reduction. Metabolic responses of obese subjects to starvation and low-calorie ketogenic and nonketogenic diets. J Clin Invest 1976;58(3):72230. doi: 10.1172/JCI108519.

18. Foster DG, Wyatt RH, Hill OJ, McGuckin BG, Brill C, Mohammed BS, et al. A randomized trial of a low-carbohydrate diet for obesity. N Engl J Med 2003;348(21):82-90. doi: 10.1056/NEJMoa022207.

19. Nettleton AJ, Jebb S, Riserus U, Koletzko B, Fleming J. Role of dietary fats in the prevention and treatment of the metabolic syndrome. Ann Nutr Metab 2014;64(2):167-78. doi: 10.1159/000363510.

20. Sackner-Bernstein J, Kanter D, Kaul S. Dietary intervention for overweight and obese adults: comparison of low-carbohydrate and low-fat diets. A meta-analysis. PLoS One 2015;10(10):e0139817. doi: 10.1371/journal. pone.0139817.

21. Naude EC, Schoonees A, Senekal M, Young T, Garner P, Volmink J. Low carbohydrate versus isoenergetic balanced diets for reducing weight and cardiovascular risk: a systematic review and meta-analysis. PLoS One 2014;9(7):e100652.
22. Bazzano AL, Hu T, Reynolds K, Yao L, Liu Y, Chen CS, et al. Effects of low-carbohydrate and low-fat diets: a randomized trial. Ann Intern Med 2014;161(5):309-18. doi: 10.7326/M14-0180.

23. Scholl J. Traditional dietary recommendations for the prevention of cardiovascular disease: do they meet the needs of our patients? Cholesterol 2012;2012:367898. doi: 10.1155/2012/367898.

24. Jovanovski E, Zurbau A, Vuksan V. Carbohydrates and endothelial function: is a low-carbohydrate diet or low-glycemic index diet favourable for vascular health? Clin Nutr Res 2015;4(2):69-75. doi: 10.7762/cnr.2015.4.2.69.

25. Hu T, Bazzano AL. The low-carbohydrate diet and cardiovascular risk factors: Evidence from epidemiologic studies. Nutr Metab Cardiovasc Dis 2014;24(4):337-43. doi: 10.1016/j.numecd.2013.12.008.

26. Ruth RM, Port MA, Shah M, Bourland AC, Istfan NW, Nelson KP, et al. Consuming a hypocaloric high fat low carbohydrate diet for 12 weeks lowers C-reactive protein and raises serum adiponectin and high density lipoprotein-cholesterol in obese subjects. Metabolism 2013;62(12):1779-87. doi: 10.1016/j.metabol.2013.07.006.

27. Shaafi S, Mahmoudi J, Pashapour A, Farhoudi M, Sadigh-Eteghad S, Akbari H. Ketogenic diet provides neuroprotective effects against ischemic stroke neuronal damages. Adv Pharm Bull 2014;4(2):479-81. doi: 10.5681/apb.2014.071.

28. Auvin S. Non-pharmacological medical treatment in pediatric epilepsies. Rev Neurol 2016;172(3):182-5. doi: 10.1016/j.neurol.2015.12.009.

29. Amari A, Turner Z, Rubenstein JE, Miller JR, Kossoff EH. Exploring the relationship between preferences for high fat foods and efficacy of the ketogenic and modified Atkins diets among children with seizure disorders. Seizure 2015;25:173-7. doi: 10.1016/j.seizure.2014.11.001.

30. Allen BG, Bhatia SK, Anderson CM, Eichenberger-Gilmore JM, Sibenaller ZA, Mapuskar KA, et al. Ketogenic diets as an adjuvant cancer therapy: History and potential mechanism. Redox Biol 2014;2:963-70. doi: 10.1016/j.redox.2014.08.002.

31. Klement RJ. Restricting carbohydrates to fight head and neck cancer is this realistic? Cancer Biol Med 2014;11(3):145-161. doi: 10.7497/j. issn.2095-3941.2014.03.001.

32. Klement RJ, Sweeney RA. Impact of a ketogenic diet intervention during radiotherapy on body composition: I. Initial clinical experience with six prospectively studied patients. BMC Res Notes 2016;9:143. doi: 10.1186/ s13104-016-1959-9.

33. Schmidt M, Pfetzer N, Schwab M, Strauss I, Kämmerer U. Effects of a ketogenic diet on the quality of life in 16 patients with advanced cancer: a pilot trial. Nutr Metab (Lond) 2011;8(1):54. doi: 10.1186/1743-7075-8-54.

34. Jurczak A, Olczak-Kowalczyk D, Bąk E, Kościelniak D, Gregorczyk-Maga I, Papież M, et al. Próchnica zębów - od czasów starożytnych do współczesności. Nowa Stomatol 2014;4:183-8.

35. Kaidonis J, Townsend G. The 'sialo-microbal-dental complex' in oral health and disease. Ann Anat 2015;203:85-9. doi: 10.1016/j.aanat.2015.02.002.

36. Adler CJ, Dobney K, Weyrich LS, Kaidonis J, Walker AW, Haak W, et al. Sequencing ancient calcified dental plaque shows changes in oral microbiota with dietary shifts of the Neolithic and Industrial revolutions. Nat Genet 2013;45(4):450-5. doi: 10.1038/ng.2536.

37. Jańczuk Z. Stomatologia zachowawcza. Zarys kliniczny. Warszawa: PZWL; 2008.

38. Cadotte M, Dinnage R, Tilman GD. Phylogenetic diversity promotes ecosystem stability. Ecology 2012;93(8):223-33.

39. Petchey O, Gaston K. Effects on ecosystem resilience of biodiversity, extinctions, and the structure of regional species pools. Theor Ecol 2009;2(3):177-87.

40. Price WA. Nutrition and physical degeneration. A comparison of primitive and modern diets and their effects. New York-London: Medical Book Department of Harper \& Brothers; 1939.

41. Baumgartner S, Imfeld T, Schicht O, Rath O, Persson RE, Persson GR. The impact of the stone age diet on gingival conditions in the absence of oral hygiene. J Periodontol 2009;80(5):759-68.

42. Al-Ahmad A, Roth D, Wolkewitz M, Wiedmann-Al-Ahmad M, Follo M, Ratka-Kruger $P$, et al. Change in diet and oral hygiene over an 8-week period: effect on oral health and oral biofilm. Clin Oral Investigation 2010;14:391-6. 